\title{
DE
}

\section{CLIMATE CHANGE, URBANIZATION AND LIVELIHOOD PERSPECTIVE OF INDIGENOUS FISHING COMMUNITIES OF MUMBAI, INDIA}

DOI 10.2478/pesd-2014-0029

PESD, VOL. 8, no. 2, 2014

\author{
Sibananda Senapati ${ }^{1}$, Vijaya Gupta ${ }^{1}$
}

Key words: fishery, urbanization, climate change, pollution, Mumbai.

\begin{abstract}
This study is an attempt to derive the socio-economic implications of climate change and other environmental issues pertaining to fishing communities residing in and around Mumbai, India. A substantial number of populations in Mumbai city are the fishing communities, popularly known as 'Koli'. They are the earliest inhabitants of the city. Coastal cities are most productive as well as most vulnerable to environmental changes. They support a number of economic activities which include fishing, agriculture, urbanization, real estate, tourism, transport, oil exploration etc. As a result, the anthropogenic pressure on coastal cities is increasing. Koli communities in Mumbai encounter diverse socio-economic and climatic pressures including sea level rise, floods, storms, etc. The implications of climate change on Koli communities as well as other environmental issues pertaining to fishing villages in Mumbai are discussed in detail in this study. Five fishing villages from Mumbai are selected for a primary study based on a structured questionnaire. Nearly 200 households are surveyed in a period over six months in 2011-12, finally 182 households information is considered for further analysis. On the basis of the findings, this study suggests that issue of lack of asset formation and financial insecurity among young fishermen may be taken care by linking the fisheries societies in Mumbai and in other regions with the support from local governments. The benefits of subsidies, insurance may be distributed progressively based on their financial needs to all fishermen rather than benefiting the large scale fishermen alone.
\end{abstract}

\section{Introduction}

India has more than $8000 \mathrm{~km}$ long densely populated, fragile and highly productive coastal ecosystem which includes a huge array of marine biological

\footnotetext{
${ }^{1}$ National Institute of Industrial Engineering (NITIE), Vihar Lake Road, Mumbai-400087, India.sibanandaeco@gmail.com
} 
diversity and the largest number of commercial fish species in the world. Fish is an important source of food as well as employment, income and foreign exchange for India (ICSF, 2001). The fishery sector supports a diverse range of livelihood activities, from production and processing to marketing and ancillary functions. Traditionally marine fishing was a group activity, with each member contributing according to their capacity. However, presently there has been a change in fishing operations from subsistence based traditional occupation to profit oriented business, which has seriously threatened traditional skills, knowledge, and employment of artisanal fishermen (Salagrama, 2006). The diffusion of new technologies has benefited only a few fishermen in the sector. Geographical and occupational migration by fishermen in search of livelihood is increasing, and much of this burden falls on the women and younger generations. The change in climate will further affect the fish distribution which will lead to increase in fishing efforts (IPCC, 2007).

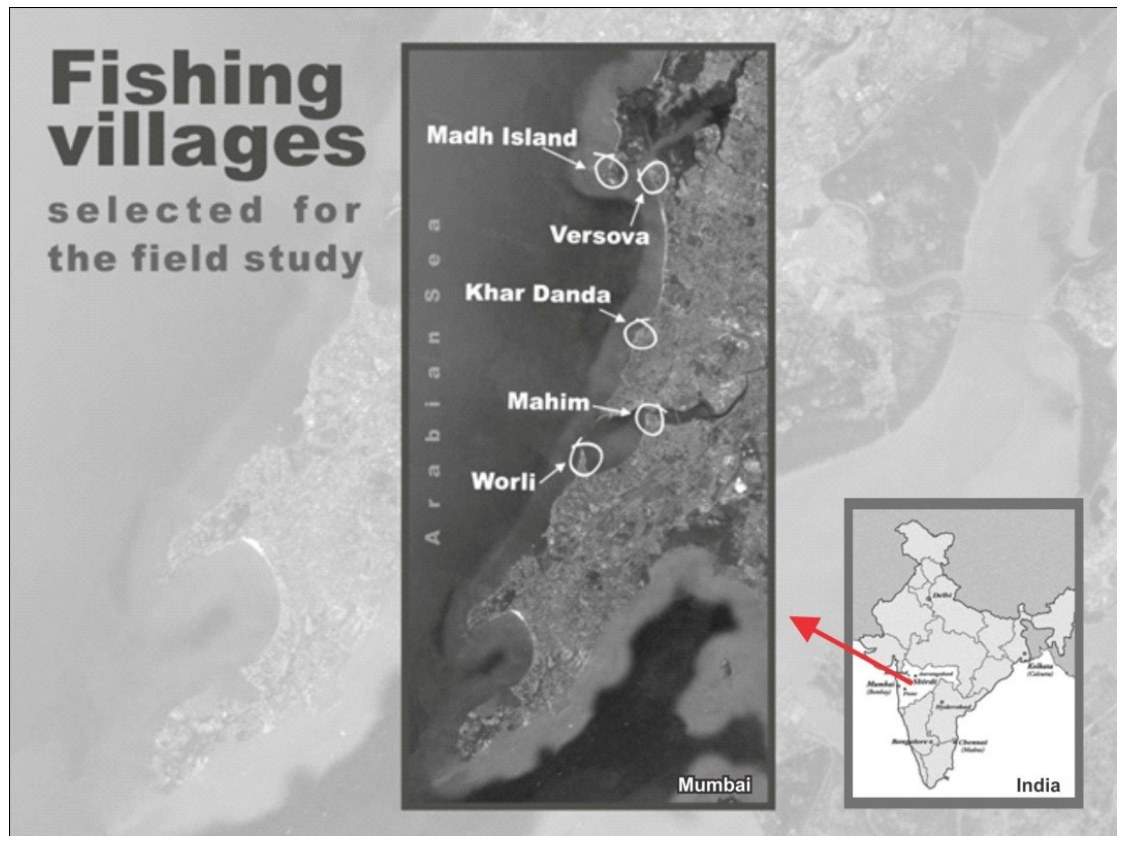

Fig. 1. Fishing village surveyed for the present study.

The Energy Research Institute (TERI), New Delhi has estimated that a 1metre Sea Level Rise (SLR) will affect $5763 \mathrm{~km}^{2}$ (or $0.41 \%$ ) combined area of the coastal states in India (TERI, 1996), since coastal fishing communities live close to the 
sea, they are going to bear heavy burden of rising sea level. Fishing communities are also known for their reactive or adaptive nature (Coulthard, 2008). Therefore it is appealing to study the implications of climate change and other environmental changes, their marketing behavior and other social and economic aspects of these indigenous fishing communities.

This study is both descriptive and empirical in its framework. Mumbai is the most vulnerable coastal district in India in terms of its physical and economic exposure to climate change (TERI, 1996). The unprecedented changes in rainfall frequently create problems. Such as flooding, storms etc to the city. The fishing communities residing close to the sea and in low lying areas are the most affected. The livelihoods of fishing community get threatened due to unfavorable socioeconomic and climatic conditions which make them weak to further cope with the city's living condition. Therefore this study selects Mumbai as its study area and coastal fishing communities living in Mumbai to undertake a household level primary survey. Figure 1 below shows the pictorial view of Mumbai and the fishing villages surveyed for the present study.

\section{Socio-economic Profile of the Fishing Households}

Socio-economic characteristics of the households play a very important role in describing and assessing the vulnerability of households to climate change. The first five sections of the questionnaire deal with various household socio-economic parameters like (1) Households' demographic information, (2) Occupation, (3) Family income and expenditure (4) Households' physical assets. In the following table 1 the above issues are presented and analyzed subsequently.

Table 1 presents the descriptive statistics on the demographic features of the respondent surveyed. A majority of the respondents are young with $64.3 \%$ falling within the age group of 31-50, the mean age being 43. A majority of them, about $89 \%$, are male respondents and head of the household. Women in the fishing villages keep themselves busy in household works as well as in selling and marketing activities, so it was difficult to speak with them. Male members of the households take a break after their fishing trip and during this time their responses in the predesigned questionnaire are recorded. In Koli households, marriages are held at a very young age, so that as the young fisherman go for fishing, the wife takes charge of marketing, thus almost 93\% fishermen in the survey are married. Another reason for this could be the large proportion of nuclear family pattern in the fishing villages. In the survey $68 \%$ of the families are nuclear family and only $32 \%$ are joint families. The nuclear family heavily depends on its female members. In the survey only $15 \%$ of the respondents are found as illiterate, whereas nearly $75 \%$ of them studied up to matriculation. In most of the fishing villages the government-run schools are up to matriculation (10th standard). The fishermen 
forced their children into fishing from an early age, mostly at the age of their matriculation. In terms of religion, $86 \%$ of the respondents surveyed are 'Hindu Kolis', and the rest are 'Christian Kolis' Chirstian Kolis mostly reside in the villages like Madh and Mahim.

Tab. 1. Demographic characteristics (total $\mathrm{N}=182$ )

\begin{tabular}{lcc}
\hline \multicolumn{1}{c}{ Variable } & Frequency & Percentage \\
\hline Age (in Years) & 23 & \\
Less than 30 & 64 & 12.6 \\
$31-40$ & 53 & 35.2 \\
$41-50$ & 29 & 29.1 \\
$51-60$ & 13 & 15.9 \\
Greater than 61 & & 7.1 \\
\hline Sex & 162 & \\
Male & 20 & 89.0 \\
Female & & 11.0 \\
\hline Marital Status & 169 & \\
Married & 13 & 92.9 \\
Unmarried & & 7.1 \\
\hline Education & 28 & \\
Illiterate & 62 & 15.4 \\
Primary & 72 & 34.1 \\
Matriculation & 18 & 39.6 \\
Higher Secondary & 2 & 9.9 \\
Graduate and above & & 1.1 \\
\hline Religion & 157 & 86.3 \\
Hindu & 25 & 13.7 \\
Christian & & \\
\hline Caste & 11 & 6.0 \\
Scheduled Caste (SC) & 22 & 12.1 \\
Scheduled Tribe (ST) & 6 & 3.3 \\
Other Backward Caste (OBC) & 143 & 78.6 \\
Special Backward Caste (SBC) & & \\
\hline Type of family & 124 & 68.1 \\
Nuclear Family & 58 & 31.9 \\
Joint Family & & \\
\hline Sol Fiel Swy (2011-12) & & \\
\hline & & \\
\hline
\end{tabular}

Source: Field Survey (2011-12) 


\subsection{Occupation}

Majority of the respondents (87.4\%) surveyed are active fishermen and fishing is the full time occupation for nearly $98 \%$ of the respondents. Very few respondents consider fishing to be a part time occupation and work in other sectors like, boat making, and do businesses or work in private sectors. For $11.5 \%$ of the respondents, mostly women headed households, those who do not possess any boats, for them marketing of fish is the major occupation. The women members purchase fish from others in the village and sell it in nearby markets. Net making and fish shed collection are major fishing allied occupations, however nowadays migrants from other parts of the country as well as from Maharashtra are increasingly involved in these activities as a result of which, fishermen especially women members in the fishing households are losing their traditional job. Continuous reduction in fish availability and increase in competition among fishermen is also forcing young population in fishing villages to look for other occupations. Table 2 shows the frequency of various occupations of the respondents.

Table 2. Occupation of the respondents

\begin{tabular}{|c|c|c|}
\hline Occupation & Frequency & Percentage \\
\hline Fishing & 159 & 87.4 \\
\hline Marketing & 21 & 11.5 \\
\hline Net-Making & 2 & 1.1 \\
\hline \multicolumn{3}{|c|}{ Occupation type } \\
\hline Full time & 176 & 96.7 \\
\hline Part time & 6 & 3.3 \\
\hline Source: Field Survey (2011-12)
\end{tabular}

\subsection{Households' Income}

Fishing is the primary and major source of income for $87 \%$ of the households surveyed and for $97 \%$ of the households fishing is the full time occupation. The minimum income from fishing is Rs. 40,000 per year/per household and the highest income is Rs. 2, 50, 000 per year/ per household with mean income of Rs. 92,280 and median income of Rs. 80,000. The following (Figure 2) shows that only 5.5\% of the respondents surveyed have observed an increase in their income, whereas over $19 \%$ of the households observed a decrease in their income over the years. Over $51 \%$ observed a moderate rise in income. 


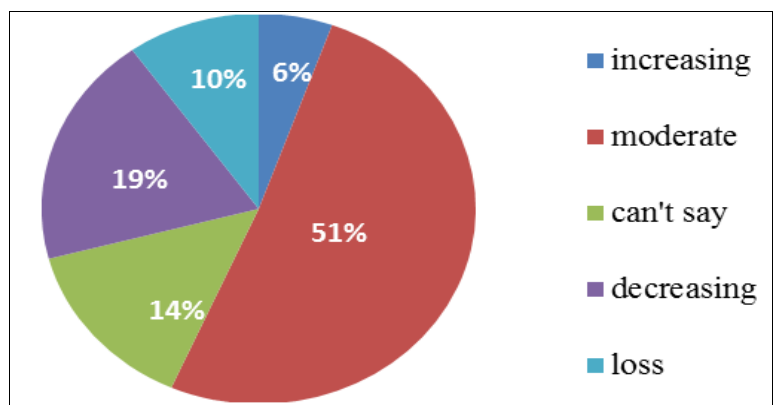

Figure 2. Nature of income over the years from fishing and related activities; Source: Field Survey (2011-12)

\subsection{Households' Amenities and Assets}

The availability of basic household amenities like house and other physical assets including boats, types of boats, and types of nets are very much important in defining the vulnerability of fishermen. The characteristics of the dwelling/type of house (Katcha/Pucca) define the resilience/adaptive capacity of households to flood, storm and SLR. Fishing villages are situated very close to the sea and are very often affected by high storm, cyclones and flood. Although most of the houses in the fishing villages surveyed are Pucca (51.6\%) and Semi Pucca (48.4\%), they are often affected by floods and high tides. In Mahim a few of the households have to vacate their house in the month of June and July because of the high tide. The houses in Koliwada are very small. Fishermen usually possess huge fishing equipments including fishing nets, plastic containers, oil containers etc. Fishermen are losing their traditional place to store all these equipments including the places they used to dry fish and berth their boats. The dry fish business is an alternative business but it is lost completely. There are increasing cases of theft of these equipments in the fishing villages. Fishermen are losing these places because of the increase in urbanization and development projects near the coast. The fishermen also do not have property rights on the land they are living, although they are living in these places for a long time. Fishermen housing schemes, which are planned earlier (GOI, 2004) are not properly implemented in the fishing villages.

The other household amenities like electricity, drinking water, and telephone/mobile connection are easily available to fishermen and all the households surveyed have electricity and drinking water facilities. However, fishermen are not getting any subsidies towards the electricity and drinking water which adds to their financial burden, especially for small and poor fishermen. Radio, which was earlier considered as an important source of news and communication is now substituted by mobile phones, television and other 
electronic equipments like GPS, fish finder etc. From the survey 64 fishermen are found using mobile phone, 37 use satellite phone, 17 use GPS (Figure 3). These instruments also help them in accessing information related to climate, storm, cyclones, winds, etc. Others include, television, radio etc.

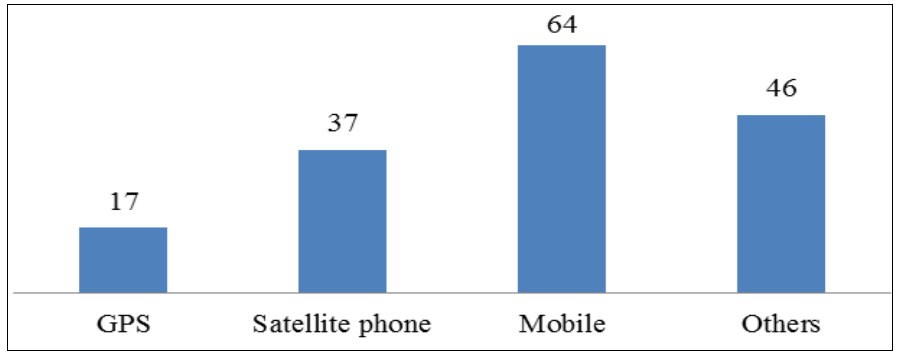

Fig. 3. Types of communication gadgets fishermen use;

Source: Field Survey (2011-12)

Boat is the primary factor of production for fishermen and the types/categories of boats reflect the economic well being of the household. Boats are divided here into three categories: mechanized, motorized and non motorized/country boats. Table 3 shows that 164 households having boats, out of which $53(32 \%)$ possess mechanized boats, $96(58 \%)$ have motorized boats and only $15(9 \%)$ have country boats. 18 respondents do not have boats at all. Versova and Mahim having more mechanized boats, on the other hand the fishermen from Khardanda, Madh and Worli possess more motorized boats. Fishermen get subsidies in the form of soft loans towards making mechanized boats. But there are many reasons such as competition, increasing cost of labour, fish depletion, climate change etc. which forced most of the fishermen to sell their mechanized boat. They are now fishing through motorized and country boats in nearby waters.

Table 3. Types of boats

\begin{tabular}{|l|c|c|}
\hline \multirow{2}{*}{ Types } & \multicolumn{2}{c|}{ Own Boats } \\
\cline { 2 - 2 } & Yes & Total \\
\hline 1. Mechanized & $53(32.3 \%)$ & \multirow{2}{*}{$1640.1 \%)$} \\
\hline 2. Motorized & $96(58.5 \%)$ & $18(9.9 \%)$ \\
\hline 3. Non-motorized/country boats & $15(9.1 \%)$ & $\mathbf{1 8 2}(\mathbf{1 0 0 \% )}$ \\
\hline 4. No boat & $18(9.9 \%)$ & \\
\hline \multicolumn{2}{|c|}{ Total } & \\
\hline
\end{tabular}

Source: Field Survey (2011-12) 


\subsection{Households' Consumption Expenditure}

Consumption pattern of the household is one important factor for measuring vulnerability. The study by Sumaila et al. (2011) posit that the capital costs, that is, the cost of vessels, fishing gear, processing plants and so on, would also be affected by climate change (by involving additional capital for fishing and processing operations to adapt to climate change impacts). The poor families generally lack adequate means to cope with climate change and other problems. On the other hand, rich households suffer less damage due to their financial capabilities to withstand the damages and due to their high adaptive capacities. The household expenditure is here divided into two categories: consumption expenditure of household on primary goods and utility bills such as, food, water bill, electricity, health etc. and expenditure towards fishing like, boat repair, net repair, fuel cost, labour cost etc.

Table 4. Annual household consumption expenditure and fishing costs (in Rupees)

\begin{tabular}{|l|c|c|c|c|}
\hline & Mean & Median & Minimum & Maximum \\
\hline Food & 57037.91 & 50000 & 5000 & 150000 \\
\hline Drinking water & 859.61 & 900 & 100 & 3000 \\
\hline Health & 2191.48 & 1000 & 0 & 50000 \\
\hline Education of children & 6059.66 & 1500 & 0 & 100000 \\
\hline Electricity & 7497.80 & 7200 & 1000 & 18000 \\
\hline $\begin{array}{l}\text { Other household } \\
\text { expenditure }\end{array}$ & 6137.363 & 5000 & 1000 & 50000 \\
\hline \multicolumn{4}{|l|}{ Annual fishing costs } \\
\hline Boat repairing & 24529.95 & 11000 & 0 & 200000 \\
\hline Net repairing/purchasing & 18266.48 & 15000 & 0 & 100000 \\
\hline Fuel (Petrol or diesel) & 250531.3 & 75000 & 0 & 1500000 \\
\hline Transport & 506.60 & 0 & 0 & 10000 \\
\hline Storage & 14213.19 & 2000 & 0 & 75000 \\
\hline Labour & 107601.6 & 75000 & 0 & 600000 \\
\hline
\end{tabular}

Source: Field Survey (2011-12)

Note: ' 0 ' here shows those households who do not possess a boat

Table 4 provides the details of annual household expenditure. The mean expenditure on food for the respondents is Rs.57,000 with minimum expenditure of Rs.5000 and maximum of Rs.1,50,000. The mean annual expenditure for boat repairing is close to Rs. 25,000 per year. Every year before the starting of fishing season, fishermen spend a huge amount on repairing and making the boat ready for fishing. The annual mean expenditure towards net repairing is Rs. 18,000. Due to change in wind currents, and due to increase in storms, fishermen's spending on net repairing is increasing. The average annual expenditure on fuel is close to 
Rs.2,50,000 with minimum expenditure of Rs.75,000 and maximum expenditure of Rs.15,00,000. The expenditure on storage and ice is also increasing with the rise in temperature and climate, the mean expenditure on storage is Rs.14,213 yr. Similarly the annual mean expenditure on labour is Rs.10,7600 yr.

\section{Marketing Issues}

Marketing of fish is traditionally confined to Koli women. However, with the entry of middlemen to the fishing business there is an increase in the export of fish and availability of transport and storage facility. In the survey $66.5 \%$ of the respondents are selling fish to middlemen. The major reason for selling fish to middlemen is that most of the fishermen borrow money from them (Figure 4). Fishing is a seasonal business and every year for a particular period, generally in monsoon time, fishermen do not go for fishing. During that period fishermen depend upon their savings as well as borrow money from middlemen. Similarly at the start of the fishing season they also borrow money from middlemen for purchasing fishing equipments. Sometimes fishermen do not want to spend money on transporting fish to the market, so the middlemen reach at the fish landing site and directly buy fish from fishermen. The price of fish also depends on market forces and there is absence of any regulation from the government. Therefore most of the time middlemen cheat fishermen by paying very low price and later selling fish at a higher price in other markets. Sale of dry fish is also one of the major sources of earning for fishermen. The small fish and other fishes having much lesser value are usually dried and sold in the market. However, this business is also declining, only a few fishermen from Madh and Khar village are still doing this dry fish business.

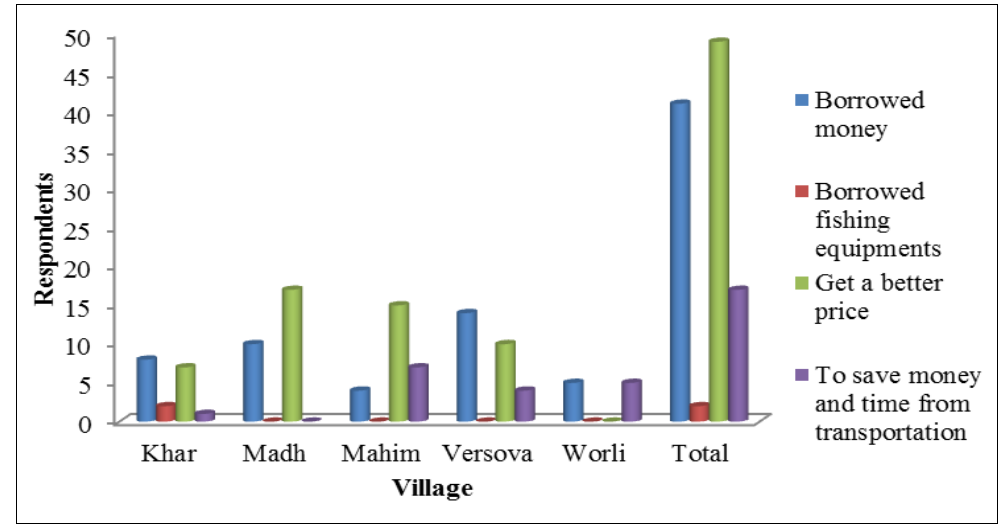

Fig. 4. Reason for selling fish to middlemen; Source: Field Survey (2011-12) 


\section{Health Issues}

Health is an important socio-economic aspect of the fishery based livelihood. The fishing villages are very congested and there is little open space left in the area. The slum like places are always exposed to diseases like malaria, dengue etc. Climate change is also one of the major reasons for increasing health risks in fishing villages (CMFRI, 2010). In case of diseases and illness fishermen prefer to go to public hospitals, however in some villages like Madh and Khar a majority of fishermen prefer to go to private hospitals. The medical facilities provide by the government are not available nearby, rather there are a number of private clinics and fishermen prefer to go to nearby clinics in case of emergency. However, these private clinics charge more and they have their own timings.

\section{Urbanization}

Rapid industrialization, urbanization and a lack of control over the dumping of chemicals and pollutants into the Arabian Sea are some of the major causes of concern for fishing villages. As the fishing villages are situated close to the sea, all these wastes often reach the fishing villages causing serious health and other issues. According to the study conducted by National Institute of Oceanography

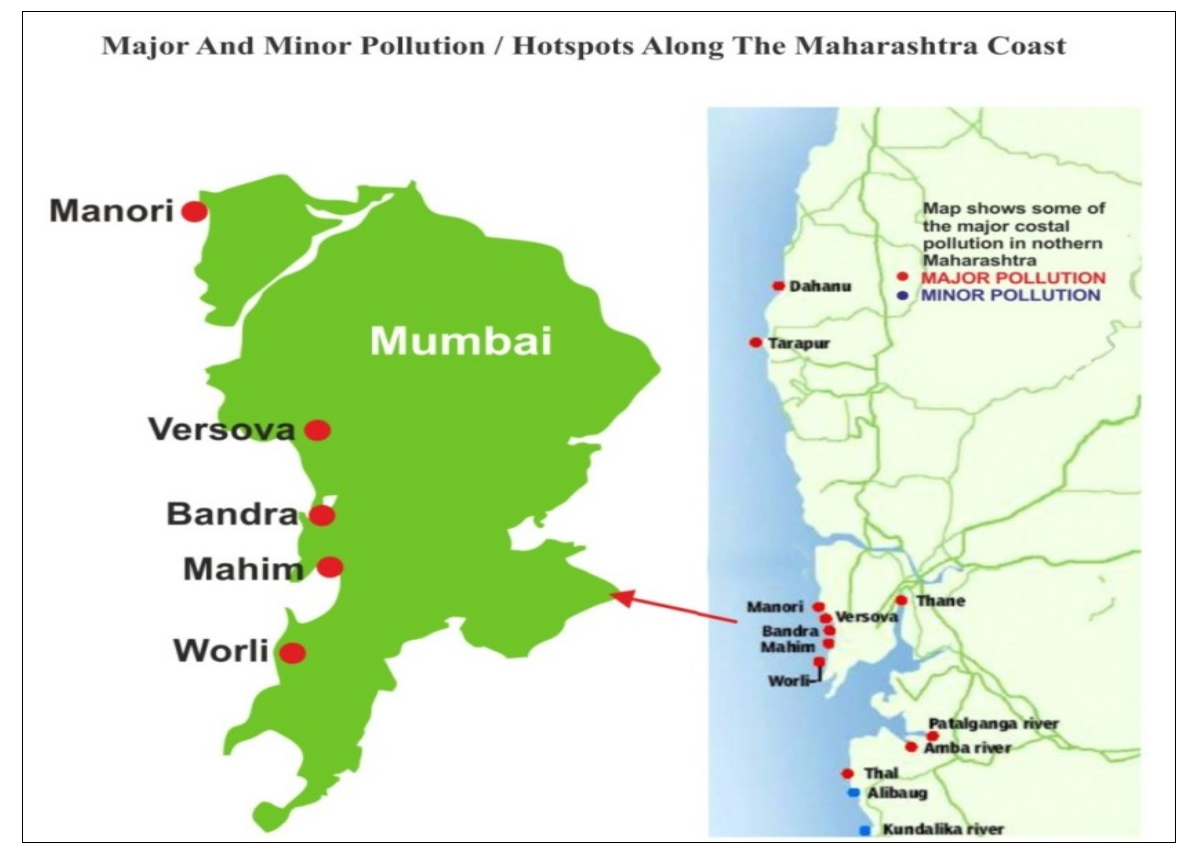

Fig. 5. Major and Minor pollution along the Maharashtra coast 
(NIO) for the Maharashtra Pollution Control Board (MPCB), the entire coast line of Maharashtra is the most polluted coastline in India (TOI, 2010). The area from Dahanu to Mulund, along the northern coastline of Maharashtra is most polluted due to the presence of organic substance (chemical and domestic pollutants) in the water. There is also more petroleum contamination in the creeks of northern Maharashtra as compared to the South. Three of the five fishing villages selected for the current study (Versova, Mahim and Worli) are among the major polluted region found in that study (figure 5).

According to $95 \%$ of the respondents urbanization is a major problem affecting their livelihood. Water pollution, destruction of mangroves, increase in construction activities and increase in port activities are some of the related issues of rapid urbanization and industrialization. Due to this, the fish catch in the creeks is less than in open-shore waters. There could be a risk to the breeding of commercially important fish in the long run seriously affecting the natural balance of fish availability. In the following Figure 6, the respondents' ratings of the issues of urbanization are presented.
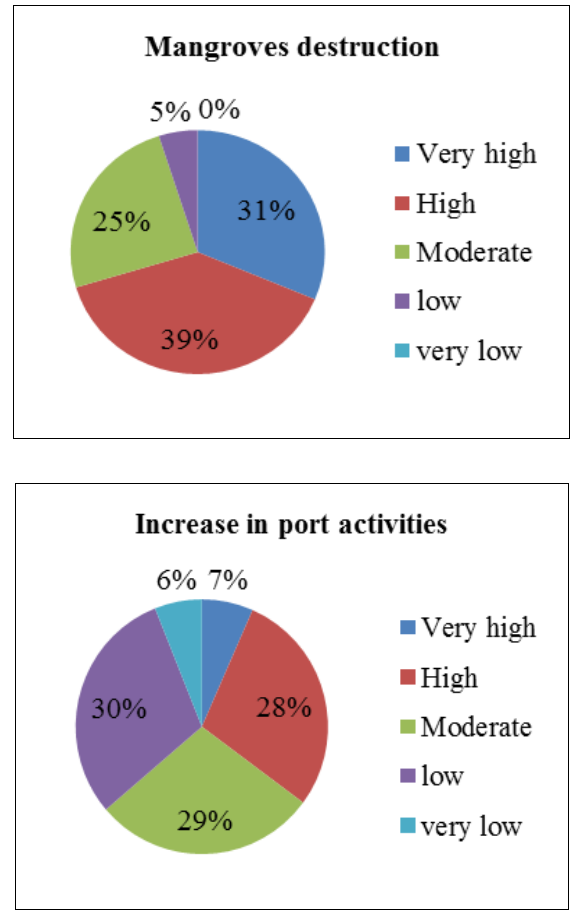
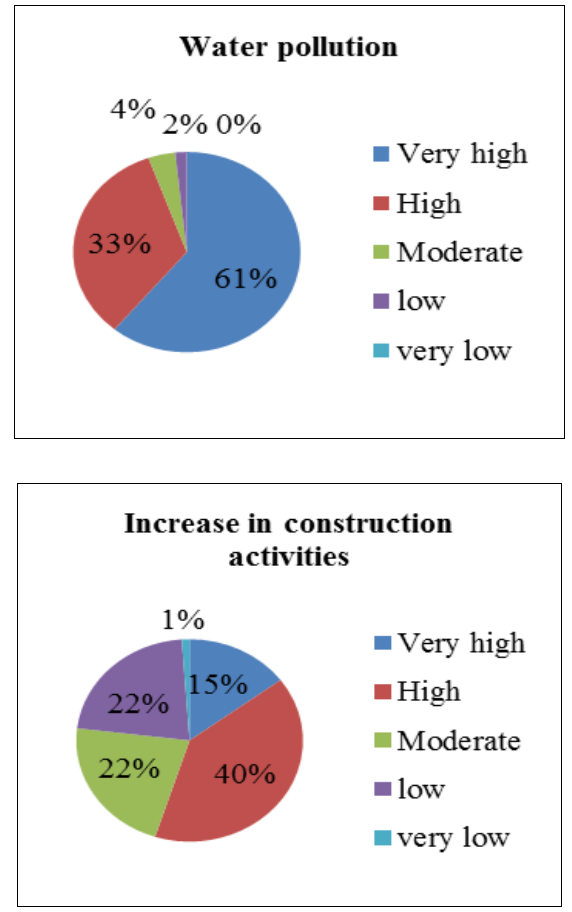

Figure 6. Urbanization issues; Source: Field survey (2011-12) 


\section{Findings and Conclusion}

Descriptive analysis of the primary survey data shows that fishermen in Mumbai are young (mean age year 43 ) and educated $(75 \%$ of the respondents studied up to matriculation), and for majority of them (98\%) fishing is the only and full time occupation. However, there is a huge disparity in the level of income, and different fishing practices are adopted by fishermen in different fishing villages. For example in Versova and Mahim fishermen used more mechanized boats whereas in Madh, Worli and Khar fishermen possess more motorized boats. The category of boat is one important factor which decides the economic well-being of the fishermen. The analysis of expenditure data of fishermen reveal that the expenditure towards boat repairing and net purchasing including the costs of fuel and labour are high and affecting financial stability of the fishermen in Mumbai. The entry of middlemen and migrants into fishing business is affecting the Koli women, in many parts of the city women members are losing their traditional job of selling fish. Male members of fishing household suffer from more health related problems compared to others. This could be because of their hard labour, and exposure to different types of weather, rainfall, temperature in the sea. Though there are several government run hospitals in and around Mumbai, fishermen often preferred to go to the private clinics in their neighborhood. The clinics do not follow a particular time table, and in case of emergency fishermen are finding it difficult to get immediate treatment. The issue of urbanization and the observation of fishermen towards related impacts of climate change like water pollution, destruction of mangroves show the seriousness of the problem. Water pollution is a major challenge for fishermen (61\% ranked the problem very high) and since fishermen depend mostly on sea, the polluted coastal water is affecting them seriously in terms of decrease in fish availability, increase in heath issues etc.

\section{References}

S. Coulthard, (2008) Adapting to Environmental Change in Artisanal Fisheries-Insights from a South Indian Lagoon. Global Environmental Change. 18, pp. 479-489.

GOI (2004) Comprehensive Marine Fishing Policy. Government of India, Ministry of Agriculture Department of Animal Husbandry \& Dairying, New Delhi.

ICSF (2001) Forging unity: coastal communities and the Indian Ocean's future", International Collective in Support of Fishworkers (ICSF), International Ocean Institute (IOI), Indian Institute of Technology (IIT), Madras, Chennai. Downloaded from www.icsf.net/icsf2006/jspFiles/wif/english/pdfs/IO\%20Statement\%202001.pdf

IPCC (2007) Climate Change 2007: Impacts, Adaptation and Vulnerability. Contribution of Working Group II to the Fourth Assessment Report of the Intergovernmental Panel on Climate Change, Cambridge University Press, Cambridge. 
V. Salagrama, (2006) Trends in Poverty and Livelihoods in Coastal Fishing Communities of Orissa State, India, Food Agricultural Organisation (FAO), Fisheries Technical Paper, 490.

U. R. Sumaila, L. W. W. Cheung, Y. W. V. Lam, D. Pauly, and S. Herrick, (2011) Climate Change Impacts on the Biophysics and Economics of World Fisheries, Nature Climate Change, 1301, pp. 1-8.

TERI (1996) The Economic Impact of a One Metre Sea Level Rise on the Indian Coastline: Method and Case Studies, Report submitted to the Ford Foundation, Tata Energy Research Institute. New Delhi.

TOI (2010) The Times of India Mumbai; Date: Jul 3, 2010; Section: Times City; Page: 8 